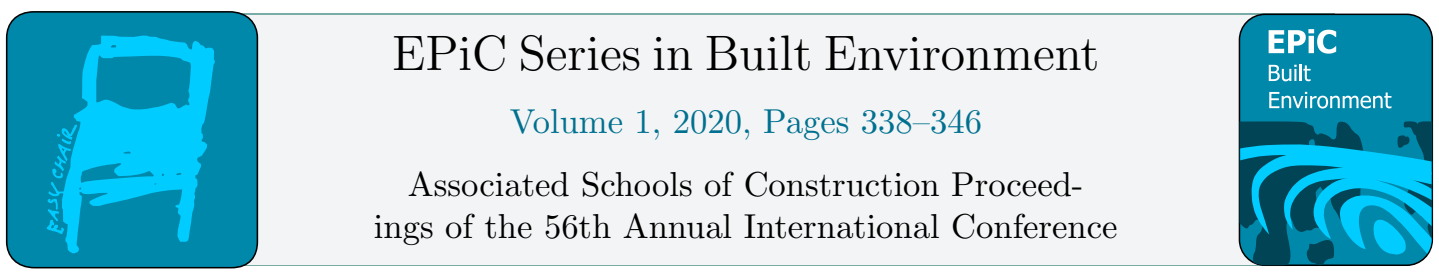

\title{
Construction Surety Bonding Criteria: The US Perspective
}

\author{
Manideep Tummalapudi \\ Colorado State University \\ Fort Collins, USA
}

\author{
Christofer M Harper \\ Colorado State University \\ Fort Collins, USA
}

\author{
John Killingsworth \\ Colorado State University \\ Fort Collins, USA
}

\begin{abstract}
In the United States, construction contracts require that contractors submit surety bonds, hence shifting the contractor's risks to the sureties. In order to take on the risks of project completion, the sureties employ a complex time-consuming evaluation process that assesses several factors of a contractor that are subjective to make a surety credit recommendation. Several small and emerging contractors find it very difficult to attain bonding capacities as they do not know the factors that go into the sureties' consideration to extend surety credit. The purpose of this study is to identify the surety bonding criterion that influences bonding decisions through a series of interviews with surety professionals possessing extensive experience in the bonding evaluation process. The outcome is a list of factors that underwriters consider in issuing a surety credit to contractors. Understanding the surety bonding criteria employed by underwriters enhances contractors' ability to secure required bonding capacities for their future projects.
\end{abstract}

Key Words: Surety Credit, Construction Bonding Criterion, Contractor Awareness, Capital, Capacity and Character.

\section{Introduction}

In the United States, construction is one of the major contributors to the economy, employing more than 8 million employees and creating nearly USD 1.3 trillion worth of structures each year. Construction projects are taking place all over the country contributing 6.5\% to the national GDP (U.S Bureau of Economic Analysis, 2018). The construction sector has witnessed record growth since rebounding from the Great Recession (2008-10) and has witnessed vast inflow of funds into construction. The construction sector's impact on U.S. GDP has grown by more than $21 \%$ since its low point in 2011 (U.S Bureau of Economic Analysis, 2018), indicating that the industry has been undergoing a moderate pace of growth. The construction sector is expected to continue the growth and be one of the fastest-growing industries in 2020 (CIC, 2015). The industry has been consistently adding workforce, and registering more than 7\% year-on-year growth in the last 5 years. New construction put into place in the United States is among the highest in the South Atlantic and Pacific regions making the industry's outlook positive(Wang, 2019). As the construction industry picks itself up, it hosts a set of challenges too. 
Many small and mid-sized contractors entered the construction industry in the last 5 years. The U.S. had 810,295 construction firms in 2016, of which $92 \%$ were small (1 to 19 employees) (Simonson, 2017). The U.S construction industry, despite being one of the largest in the world, has a number of barriers to success, making their survival difficult. The five-year survival rate for construction businesses in the United States is merely 36.4\% (Kakkad, 2017), which means that the likelihood of a new construction company to fail is twice as high as companies that survive. The important reasons for this can be attributed to shortage of skilled labor, poor financial management, poor project selection, improper planning, surety bonding challenges, and volatile economic conditions. Generally, an overlap of these causes results in the failure of a company. One significant reason for the failure of small and medium-sized companies is their inability to secure surety bonding. These contractors have the tools and talent to complete the project, yet they struggle to attain bonding capacities, which is distancing them from winning project awards. This is often the case with new and emerging contractors seeking to grow.

Considering the current economic expansion, federal contracting is an attractive source of business for emerging small and mid-sized contractors. However, the qualification process for procuring federal contracts can be difficult as any contract more than USD 150,000 is required to furnish a performance bond and payment bond. Many private clients have also started requiring bonds considering the tight budgets and stringent timelines they are required to meet. This indicates that the contractors should be bondable in order to win work and they need to know the essential three C's (Remmen, 1989) of surety criteria (Capital, Character, Capacity) to build their surety record. Additionally, emerging contractors also face competition from larger construction firms that can obtain surety bonds at ease. The large and the growing contractors are not struggling to find work in today's environment, instead, the struggles are seen in establishing enough bonding support to handle their growing business plans. Obtaining surety credit is challenging for all contractors irrespective of their size.

Surety underwriting is a specialized and arduous process that prequalifies contractors to assure project owners that these contractors have enough capacities to perform the contract according to its terms. The surety provider offers this assurance based on their assessment of the contractor and their knowledge of both the financial and business practices of the construction industry. The surety underwriter must weigh each of these factors to determine if the contractor satisfies the bonding criteria. This research explores the key criteria which sureties examine to determine the risk associated with surety underwriting.

Contractors often feel that the surety bonding process is frustrating to understand (Russell, 1990). The more contractors understand the underwriting process, the greater their chance of positively influencing the underwriter's decision and ultimately improving their surety position. This research helps provide an understanding of the general bonding criterion in an attempt to better educate small and mid-size contractors and thereby enhancing their ability to secure required bonding for their projects. This research helps new and emerging contractors understand the bonding criterion adopted by underwriters to obtain their first bond and help develop a track record for future bonding.

\section{Research Methodology}

A qualitative research approach was selected for this study, and the data were collected through a survey questionnaire and a series of semi-structured phone interviews that also focused on additional follow up questions. A set of surety bonding criteria are developed from the interviews and were sent to the participants to rank them according to the level of importance. The principal goal of this research is to generate a broad list of surety bonding criteria that can be readily referred by the contractors. 
The authors designed the study around an in-depth literature review and conducted semi-structured phone interviews with experienced surety bonding agents and underwriters from across the United States. From the literature review conducted, the researchers developed a survey questionnaire and an open-ended interview protocol to collect data on the general criterion for surety bonding. The survey questionnaire was sent to interview participants prior to conducting the interview, and it included collecting basic details including name, company, designation, demographics, and opinion on the criterion for surety bonding. The open-ended interview questions, shown in Table 1, focused on discussing the criteria used by surety underwriters to assess contractors before issuing surety bonds.

The authors contacted several surety bonding agents within their network and the interviewees were selected based on their level of expertise, availability, location, and experience. The participant selection focused more on the experience of participants with more than 15 years in the surety bonding industry. These participants were given higher priority considering the fact that they would give insights on bonding criteria during the last several years. The authors adopted a snowballing sampling approach, wherein the authors reached out to a few known surety professionals initially extending an invitation to participate in the research. For each interviewee that accepted the opportunity to participate, they were asked for further contacts and introductions. This led to introductions to several surety professionals and nine of them were selected to be a part of the interviews. The surety bonding agents and underwriters once identified, were sent emails containing the interview protocol and consent letter explaining the aims of this research and requesting a probable time slot for the phone interview. The interviews were recorded with permission from the participants and transcribed for accuracy. The purpose of using a semi-structured interview approach was to initiate each interview with a set of openended questions that would lead to a thoughtful discussion and the flexibility to pursue appropriate follow-up and clarification questions regarding individual participant response. This gave the authors an opportunity to explore the respondent's perceptions and opinions regarding the many different surety bonding criteria used by surety agents and underwriters to assess contractors.

\begin{tabular}{|rl|}
\hline Table 1 \\
\hline Open-Ended Interview questionnaire \\
\hline Criteria for Bonding: \\
\hline 1) What are the criteria for issuing a performance bond? How do you measure the criteria? \\
2) How do you measure risk and decide on bonding capacity for companies (Per project and \\
total company)? What is the framework for measuring risk? \\
3) How does your firm define a low-risk company? A high-risk company? \\
4) What financial factors of the construction company do you look at to measure capital? \\
5ow do these factors affect their bonding capacity? \\
Other than financial factors, what are the other factors you consider in a construction firm \\
bonding capacity? Is there a formal metric for considering these factors? \\
\hline Lessons Learned, Current Condition and Future of Surety Bonding Criterion \\
\hline 1) What is the current economic trend of bonding for construction (Consider revenue, \\
construction industry growth, and current economic conditions)? \\
2) What is something that the surety producers don't like to see when they asses the \\
contractor's qualifications? \\
3) What do you think construction companies should do to increase their bonding limits \\
currently and in the near future? \\
4) Do you see bonding criterion changing in the future due to any specific reason?
\end{tabular}


Within the interview, the participants were encouraged to provide their overall opinion on construction surety standards. The open-ended questions mainly focused on understanding the general bonding criterion, current surety boding industry conditions, and its future implications. As this research intends to identify themes of bonding criterion from the interviews, the researchers used thematic coding techniques to identify both unique and repetitive criteria employed by the surety bonding agents and underwriters (Gibbs, 2007). This was achieved by manually identifying themes from the interview transcripts, and the results were subsequently classified into major categories and sub-categories.

The distribution of interview participants is provided in Table 2, which is based on the responses provided by the participant in the survey questionnaire.

\begin{tabular}{|l|c|c|c|c|}
\hline \multicolumn{5}{|l|}{ Table 2} \\
\hline \multicolumn{5}{|l|}{ Interview participant information } \\
\hline Participant & Experience & Location & Designation & Category \\
\hline Participant 1 & 20 yrs & Atlanta & Associate & Broker \\
\hline Participant 2 & $40 \mathrm{yrs}$ & Boston & Vice President & Underwriter \\
\hline Participant 3 & $35 \mathrm{yrs}$ & New Jersey & Vice President & Underwriter \\
\hline Participant 4 & $35 \mathrm{yrs}$ & Michigan & Regional Manager & Underwriter \\
\hline Participant 5 & $40 \mathrm{yrs}$ & California & Director & Broker \\
\hline Participant 6 & $35 \mathrm{yrs}$ & Hawaii & Chairman & Broker \\
\hline Participant 7 & $30 \mathrm{yrs}$ & Arizona & Associate & Agent \\
\hline Participant 8 & $30 \mathrm{yrs}$ & San Francisco & Vice President & Underwriter \\
\hline Participant 9 & $05 \mathrm{yrs}$ & Virginia & Bond Producer & Producer \\
\hline
\end{tabular}

\section{Results and Discussion}

This study utilized expert interviews to obtain information regarding the bonding criteria employed by surety bonding agents and underwriters to issue performance and payment bonds. The expert interviews were conducted via phone calls between and each phone interview on average took between 40 and 60 minutes. Based on the responses provided by participants in this research, the surety bonding criterion themes identified are organized into three different categories, namely,

1. Capacity related surety bonding criterion,

2. Capital related surety bonding criterion and

3. Character related surety bonding criterion

Capital refers to the contractor's financial strength, capacity refers to the contractor's ability to perform the project, and character refers to honesty, principals and integrity of the contractor. All participants used the terms Three C's of surety bonding, Capital, Capacity and Character (Remmen, 1989) during the interviews, emphasizing that all three factors are equally important and one factor does not supersede the others. The participants opined that a firm with impeccable capital and capacity and questionable character could still be rejected by the sureties.

A total of 49 unique surety bonding criteria were identified and each was assigned to a single category. Capital related criterion is the most frequently mentioned response and comprised almost half of the identified unique responses. Almost all participants spent more than half of the interview time discussing capital related factors. This suggests that although all three factors are equally important, the 
primary concern of the surety underwriters before issuing a performance or payment bond is the financial wellbeing of a construction firm. The perceptions of the participants on these three factors are detailed below.

\section{Capacity}

Capacity refers to the contractor's resource availability that is essential to execute a project successfully. Sureties give high weight to capacity in their assessment as it significantly influences both capital and character. Only if a firm has the capacity to execute a project within budget, it will earn capital from projects. Similarly, only if it can execute a project within a schedule, it will earn a good character rating. This explains the high importance of capacity in the assessment of sureties.

"Capacity covers a lot of things. One is, a contractor needs to have enough talented people to undertake the work they're contracted for. Also, deal with machinery and equipment that is available to them or they have access to. Capacity also has to do with, how many jobs they have and where they are. If you have five people in your organization who can run jobs and you have about ten jobs in ten different states. It's hard to say you have the capacity to properly manage and oversee those jobs. So, that's not only field workers and tradespeople but the multi-tasking for all the things that need to get done by them. So people and scenery and equipment and other things it takes to get their work done are all important. So sometimes they need legal help, that's all part of capacity" stated participant 3 , emphasizing the importance of efficiently managing the resources available.

"Many companies fail by expanding to new types of work and new geographical areas owing to competitive pressure" said one of the participants, indicating that prior success in similar work and location of projects are essential factors. "Sureties carefully analyze the backgrounds, skills and experience of key personnel in the firm and sometimes may even want to talk to them to determine the firm's capacity and competence" identified participant 2 , stressing the importance of the role of key staff members in success of a firm is a factor that is thoroughly assessed by sureties.

The capacity-related factors assessed by sureties to judge how much risk that a contractor represents based on capacity status are presented in Table 3 .

\begin{tabular}{|l|l|l|}
\hline \multicolumn{2}{|l|}{ Table 3} \\
\hline \multicolumn{2}{|l|}{ Capacity related decision factors for Surety Bonding } \\
\hline $\begin{array}{l}\text { Contractors experience and } \\
\text { skill }\end{array}$ & $\begin{array}{l}\text { Systems, processes, organization, } \\
\text { and administration }\end{array}$ & $\begin{array}{l}\text { Completion of projects } \\
\text { similar in size and scope on } \\
\text { time and budget }\end{array}$ \\
\hline Equipment resources & $\begin{array}{l}\text { Construction expertise and } \\
\text { knowledge }\end{array}$ & Current Work on Hand \\
\hline Personal resources & $\begin{array}{l}\text { Project essentials: location, scope, } \\
\text { complexity, project owner, etc. }\end{array}$ & Continuity plan \\
\hline $\begin{array}{l}\text { Business plan and } \\
\text { management of construction }\end{array}$ & $\begin{array}{l}\text { Expertise in works contractor } \\
\text { wants bonding for }\end{array}$ & $\begin{array}{l}\text { Project management and } \\
\text { field operations }\end{array}$ \\
\hline Claims and dispute history & Steady work in progress & \\
\hline
\end{tabular}




\section{Capital}

Capital refers to the financial strength and creditworthiness of the contractors. Capital measures the commitment of the contractors to absorb the financial risks of the firm. The surety underwriters interviewed in this research significantly stressed the importance of the financial wellbeing of the contractor in the underwriting process. "Only if a contractor qualifies in the financial assessment, sureties will then look at other aspects. It is not worth it to assess other aspects without a sound financial health" explained a participant. As noted by many participants, one of the most important financial measures is the audited financial reports of the contractor. This is the first thing that an underwriter uses to assess the contractor. "The sureties require audited financial statements for the last three to five years to track contractor's past financial record that helps us understand their profits, working capital, debts, and equity to evaluate their current and future financial strength," said participant 5. "The financial reports including balance sheets and financial statements are the first thing sureties' look at and sureties expect them to be legible and easily understandable. Typically, we're looking for a financial statement audited by construction focused CPA (Certified Public Accountant). A poorly prepared financial report that is not clear may reflect poorly on the contractor and affect the amount of surety credit or may even lead to surety rejection" stressed another participant explaining the importance of preparing quality financial statements.

The other important financial measures considered in capital are working capital, profitability, personal finance and reinvestment in the company. "Working Capital is a measure of contractors' liquidity and most sureties would expect to see a working capital ranging from 10-15\% percent of backlog" stated participant 3. Participant 4's supported that opinion, "Working Capital position is vital as it gives confidence to sureties that contractors will be able to finance solutions if any problems occur. The higher the working capital and net worth, the higher the bonding capacity will be", indicating that the amount of working capital directly influences the bonding limits of contractors. In terms of profit, participant 3 said "Profitability - definitely is the single most important factor which gives confidence to the sureties that the contractor is financially disciplined." Another participant stated, "Sureties want to know if the contractors are completing profitable projects. If contractors are not making profits, it is an indication of management issues and that is a concern to the sureties" emphasizing that positive history of consistent earnings certainly helps contractors to obtain bonding capacities with best terms.

On the personal finance side, one participant said, "Sureties often look for strong personal financial situation of the contractors. If the contractor fails to fulfill the contractual obligation on the project, then the surety jumps in and may suffer losses. In order to make sure that contractors are in a position to repay the losses back, sureties look for strong personal finances." Another participant mentioned, "If a firm is struggling to make money and if the contractor is willing to use personal finances to bail out the firm, sureties will be willing to bond", stressing how personal financial situations and indemnity play an important part in bonding decisions. "It is important for contractors to reinvest and retain earnings within the company as it demonstrates the contractors' commitment to build and sustain the company" stressing the importance of reinvesting in the company. "Accounts receivables is an important factor during surety evaluation that contractors often pay a deaf ear. Accounts receivable are generally considered current assets, but if any accounts receivable are aged over 90 days, then they will be removed when calculating working capital. This will directly affect contractor's bonding capacity" said participant 7 emphasizing the importance of collecting account receivables in a timely manner within 30-60 days. Participant 6 shared, "Sureties look at their cash 
flow, working capital, net worth, debt position and basic financial ratios to combine the part of it with their operating performance to see if they're making profits. Then, evaluate the risk and determine whether it's a good risk or not".

Overall, the authors note that Working capital and profitability are the most important factors that are scrutinized by Sureties in the underwriting process. The contractors with higher working capital and significant profitability would always score well in the capital evaluation, although other factors like a bank line of credit, cash flow management, and debt minimizing play a prominent role.

The list of other important capital-related surety bonding criteria identified through the interviews are presented in Table 4.

\begin{tabular}{|l|l|l|}
\hline \multicolumn{2}{|l|}{ Table 4} \\
\hline Capital related decision factors for & Surety Bonding \\
\hline Amount of Working Capital & $\begin{array}{l}\text { Good Track Record of } \\
\text { Profitability }\end{array}$ & Reinvestment in the firm \\
\hline Backlog Levels & Good Equity & $\begin{array}{l}\text { The strong personal financial } \\
\text { situation of the owner }\end{array}$ \\
\hline History of Consistent Earnings & $\begin{array}{l}\text { Strength of Balance } \\
\text { Sheet and Good } \\
\text { Financials }\end{array}$ & $\begin{array}{l}\text { The strong personal financial } \\
\text { situation of contractor }\end{array}$ \\
\hline Low Debt to Equity Ratio & $\begin{array}{l}\text { Legible Presentation of } \\
\text { Financial Statement }\end{array}$ & Personal indemnity of contractor \\
\hline $\begin{array}{l}\text { Accounts receivables not } \\
\text { exceeding 90 days }\end{array}$ & $\begin{array}{l}\text { Accounting done by } \\
\text { construction CPA }\end{array}$ & $\begin{array}{l}\text { Maintaining higher working } \\
\text { capital and net worth }\end{array}$ \\
\hline Good Cash flow and Liquidity & $\begin{array}{l}\text { Healthy Interim } \\
\text { Financial Statements }\end{array}$ & $\begin{array}{l}\text { Consistent Banking Relationship; } \\
\text { ability to borrow as necessary }\end{array}$ \\
\hline $\begin{array}{l}\text { Available bank operating Lines of } \\
\text { Credit }\end{array}$ & $\begin{array}{l}\text { Good Credit Score of the } \\
\text { Construction Firm }\end{array}$ & $\begin{array}{l}\text { Reliable Cost estimates to } \\
\text { Projects }\end{array}$ \\
\hline
\end{tabular}

\section{Character}

Character refers to a contractor's reputation in the market and is key to determining a contractor's bonding capacity. Surety underwriters look for qualities such as honesty, sincerity, integrity, fairness, and determination when they assess the character criterion. The character-related factors that are ascertained by underwriters identified through phone interviews are mentioned in Table 5 .

\begin{tabular}{|l|l|l|}
\hline \multicolumn{2}{|l|}{ Table 5} \\
\hline \multicolumn{2}{|l|}{ Character related decision factors for Surety Bonding } \\
\hline $\begin{array}{l}\text { Good reputation in the business } \\
\text { community }\end{array}$ & $\begin{array}{l}\text { Good Relationship with Bonding } \\
\text { Company }\end{array}$ & $\begin{array}{l}\text { Contractors clean } \\
\text { personal life }\end{array}$ \\
\hline $\begin{array}{l}\text { A good history of performing } \\
\text { quality work }\end{array}$ & No history of Bankruptcy & $\begin{array}{l}\text { Previous payment } \\
\text { practices }\end{array}$ \\
\hline $\begin{array}{l}\text { Faithful to sub-contractors and } \\
\text { suppliers }\end{array}$ & $\begin{array}{l}\text { Clean personal life } \\
\text { of contractor }\end{array}$ \\
\hline
\end{tabular}


Most interview participants agreed that if contractors don't meet the character criteria, they would be rejected regardless of whether they have the capital and capacity necessary to be bonded. Participant 8 noted that "Many Sureties always put character first. Because if you don't have integrity, it's hard to be a successful contractor. It's hard for a bonding company to accept a contractor as a bonding customer if the contractor is not honorable," which demonstrates the high importance of character in surety bonding criterion. Participant 4 believed "Character is a big part in the assessment. When a contractor has good capital and good capacity, it doesn't mean that sureties will write the risk, they should have a good character," which proves that the majority of sureties place importance on a contractor's character in their assessment, and it is important for contractors to stick to the promises they make to gain a more favorable position in the surety assessment. Then, Participant 5 expressed that, "Sureties also sometimes look at factors like contractor's relationship with the spouse as that may affect the performance of a company" which shows that sureties look at the personal life of contractors as they consider setbacks in personal life potentially impacting the performance of a company.

There are other important decision factors that were mentioned by the interview participants, which include communication, work in progress schedules, and accurate estimates. The importance of communication and building relationships between contractors and sureties cannot be understated. "A review of projects in the past with contractor's work in progress reports gives a fair idea of the quality of estimating department" noted participant 5, which explains that estimation skills of the contractor are included in the surety assessment as inaccurate estimates might be a sign of a contractor not having a firm grasp of the financing needed to construct a project.

After being asked to rank the critical bonding criteria identified from the interviews based on their level of importance, one participant stated, "Those items are so interconnected that the order of importance would be very account-specific" All participants perceived that all these factors are equally significant and none can be dismissed at the cost of another, indicating that all factors are crucial for contractors to maintain surety credit.

\section{Surety Assessment Concerns}

Understanding the prequalification requirements of surety underwriters is always helpful, but understanding what they don't like to see while assessing a contractor gives more insights and helps contractors better. "Deterioration of profits is a high danger signal that scares the underwriters and sureties would not be willing to extend surety credit if contractors are struggling to make profits" opined a participant talking about things that scare sureties. Another participant mentioned "Sureties do not like surprises. We want to know what the contractor is doing, important particulars about the project, new projects being bid and other critical information about operations, challenges and financial constraints, if any. Don't be afraid to open up, sureties always try helping contractors to succeed". Other concerns identified in this study as per perceptions of surety underwriters are presented in Table 6.

\begin{tabular}{|l|l|}
\hline \multicolumn{2}{|l|}{ Table 6} \\
\hline \multicolumn{2}{|l|}{ Top Surety Assessment concerns } \\
\hline Surprises & Poor Backlog \\
\hline High Under billings & Insufficient working capital \\
\hline Deterioration of profits & Poor estimation skills \\
\hline \multicolumn{2}{|l|}{ Poor cash collections; Accounts receivables over 90 days } \\
\hline
\end{tabular}




\section{Conclusion}

The purpose of this research was to understand the key criteria that influence the surety bonding decision. A total of 9 interviews were conducted with surety bonding companies, underwriters and agents from across the United States and responses were grouped into three categories 1) Capital related surety bonding criteria, 2) Capacity relates surety bonding criteria and 3) Character related surety bonding criteria. The study further provided a comprehensive list of crucial factors that are considered by sureties in the underwriting process, which includes working capital, profitability, experience, expertise and character, bank line of credit, personal financial situation, work in progress estimates, business plan, and skilled project management team. The limitations of this study include small sample size and exclusion of lending institutions, CPAs, and contractors. While this research provides details on the bonding criteria from the view of sureties and underwriters, it is important to note that this is an ongoing research study and bonding agents, as well as CPAs, lending institutions, and construction contractors, are scheduled for future research. Future research will explore the perspectives of contractors and lending institutions in regard to bonding to increase awareness of the bonding criterion. It is believed that with the findings from this research, contractors can better understand the surety bonding criterion and may be better prepared to meet the requirements of surety underwriters to establish a lasting relationship with sureties. This also ensures that contractor information is not overlooked resulting in rejection of surety credit. The study contributes to the body of knowledge through the creation of awareness to the small and emerging contractors to achieve desired surety bonding capacities in the current construction scenario.

\section{References}

CIC (2015). "Five Year Outlook for U.S. Construction Industry Looks Brighter." Retrieved from: $<$ https://www.constructiondive.com/news/the-neglected-bellwether-of-industry-stabilityfluctuating-number-of-const/400125/>

Gibbs, G. R. (2007). “Thematic coding and categorizing.” Analyzing qualitative data, 703, 38-56.

Kakkad, S.A. (2017). Business Survival in the Construction Industry in Relation to Other Businesses: A Comparative Analysis. Master's thesis, Texas A \& M University. Retrieved from: < http://hdl.handle.net/1969.1/161347>

Kangari, R. and M. Bakheet (2001). "Construction surety bonding." Journal of Construction Engineering and Management 127(3): 232-238.

McIntyre, M., and Strischek, D. (2005). "Surety bonding in today's construction market: Changing times for contractors, bankers, and sureties." The RMA Journal, 31-36. Retrieved from: $<\underline{\text { https://suretyinfo.org/pdf/TodaysMarketMay05.pdf }>}$

Remmen, A. (1989). Contract Bond Book, 45-92. National Underwriters.

Russell, J. S. (1990). "Surety industry: an overview." ASCE Journal of Management in Engineering 6(3), 323-341.

Simonson, K. (2019). The Economic Impact of Construction in the United States and Texas, Associated General Contractors of America. Retrieved from: $<$ https://files.agc.org/files/economic_state_facts/TX $\% 20$ fact $\% 20$ sheet.pdf $>$

T, Wang. (2019). "US Construction Industry - Statistics \& Facts." July 2019. Retrieved from:

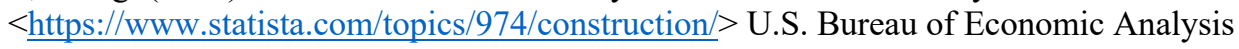
(2018). Measuring the Nation's Economy. 